\title{
ABSTRACT \\ The relationship between the speed of early initiation of breastfeeding mothers with post partum pain scale on stage four
}

Yunarsih

Akademi Keperawatan Dharma Husada Kediri

The earlyinitiation of breastfeeding mothers after the delivery happens is possible believed that can decrease the pain of delivery because it is one of distraction acts which can change the mother's focus on the pain of delivery into another stimulus. The purpose of the study is to find the correlation between the speed of breastfeeding and the decrease of pain occurrence on the mother and also give and attention the fourth stage of the labor.The method used in the study is an analytical observation (longitudinal prospective). While the population of study is some mothers who experience a vaginal birth inDahlia I Room at RSU USD Gambiran Kediri.The number of the sample is 29 mothers using a random sampling technique. The independent variable is the speed of first breast feeding and the dependent variable is the decrease of pain occurrence on the fourth stage. The datum are analyzed by ( SPSS ) T analyzed on two random sample and match to the meaningful degree of $\alpha<0,05$. The result of the study shows that there is a correlation between the speed of first breastfeeding with the decrease of pain occurrence on the mother. Therefore the conclusion of the study is that there is a correlation between the speed of the first breastfeeding and the decrease of pain occurrence of the mother, so that the researcher hope that the person on duty for the delivery process to encourage the first breastfeeding procedure to the mother and also to enlarge the knowledge of health education of the expecting mother about the essential effect of first breast feeding application.

Keyword : earlyinitiation of breastfeeding, pain and post partum on stage four 


\section{PENDAHULUAN}

Melahirkan merupakan pengalaman menegangkan, tetapi sekaligus menggembirakan. Menegangkan karena sedang dalam penantian dan merasakan nyeri. Nyeri ini akan dirasakan selama persalinan bahkan sampai setelah melahirkan(Guegue, 2008).

Inisiasi menyusui dini adalah proses alami mengembalikan bayi manusia untuk menyusu,yaitu dengan memberi kesempatan pada bayi untuk mencari dan menghisap

ASI sendiri, dalam satu jam pertama pada awal kehidupannya (Roesli Utami, 2008).

Inisiasi menyusui dini yang dilakukan sesaat setelah persalinan kemungkinan dapatmenurunkan nyeri persalinan.Inisiasi menyusui dini merupakansalah satu tindakan distraksi yang dapat merupakan pengalihan dari fokus perhatian (distraksi) terhadap nyeri persalinan ke stimulus yang lain. Menurut (Tamsuri, 2007) tehnik distraksi dapat mengatasi nyeri, berdasarkan teori bahwa aktivasi retikuler melalui sistem thalamus dan limbus medial dapat menghambat stimulus nyeri. Jika seseorang menerima input sensori yang berlebihan dapat menyebabkan terhambatnya impuls nyeri ke otak sehingga nyeri dirasakan berkurang oleh klien. Stimulus yang menyenangkan dari luar juga dapat merangsang sekresi endorfin, sehingga stimulus nyeri yang dirasakan oleh klien menjadi berkurang. Peredaan nyeri secara umum berhubungan langsung dengan partisipasi aktif individu, banyaknya modalitas sensori yang digunakan dan minat individu dalam stimulasi, oleh karena itu stimulasi penglihatan, pendengaran dan sentuhan mungkin akan lebih efektif dalam menurunkan nyeri dibanding stimulasi satu indera saja (Tamsuri, 2007).

\section{METODE}

Jenis penelitian ini adalah observasionalAnalitik. Peneliti mencari hubungan antar variabel dan dilakukan analisis terhadap data yang dikumpulkan untuk mengetahui seberapa hubungan antar variabel yang ada. Penelitian dilakukan di Ruang Dahlia I RSU USD Gambiran Kediri pada bulan Pebruari-april 2015. Dalam penelitian ini, peneliti melakukan observasi waktu yang dibutuhkan bayi sejak diletakkan di dada antara dua payudara ibu sampai bayi berhasil mencapai puting susu ibu dan menghisapnya .Intensitas nyeri ibu diukur sebelum dilakukan inisiasi menyusui dini dan sesudah inisiasi menyusui dini.Analisis bivariate menggunakan Paired $\mathrm{T}$ test dengan derajat kemaknaan 0,05

HASIL

Tabel 1.Perbedaan intensitas nyeri ibu antara pra dan pasca pada kelompok inisiasi menyusui dini kurang dari 30 menit.

\begin{tabular}{rrrrrc}
\hline $\begin{array}{l}\text { IMD } \\
<30 \\
\text { menit }\end{array}$ & n & Rerata & SD & p & Keterangan \\
\hline$P r$ & 4 & 3,4 & 1,3 & 0,022 & $\begin{array}{c}\text { Ada } \\
\text { perbedaan } \\
\text { signifikan }\end{array}$ \\
$P a$ & 4 & 1,5 & 0,5 & & \\
\hline
\end{tabular}

Berdasarkan tabel 1 didapatkan bahwa rerata intensitas nyeri pra inisiasi menyusui dini lebih tinggi yaitu 3,4 (SD 1,3) dibandingkan pasca inisiasi menyusui dini yaitu 1,5 yang 
artinya ada perbedaan intensitas nyeri pada kelompok sebelum dan sesudah dilakukan inisiasi menyusui dini kurang dari 30 menit, yang berarti intensitas nyeri ibu sesudah dilakukan inisiasi menyusui dini lebih ringan dibandingkan sebelum inisiasi menyusui dini.

Tabel2Perbedaan intensitas nyeri antara pra dan pasca inisiasi pada kelompok menyusui dini 30-60 menit

\begin{tabular}{llcccc}
\hline $\begin{array}{l}\text { IMD } \\
30-\end{array}$ & & & & & \\
60 & $\mathrm{n}$ & $\begin{array}{c}\text { Rerat } \\
\text { a }\end{array}$ & $\mathrm{S}$ & $\mathrm{p}$ & $\begin{array}{c}\text { Keteranga } \\
\mathrm{n}\end{array}$ \\
$\mathrm{meni}$ & & & & & \\
$\mathrm{t}$ & & & & & \\
\hline Pra & 2 & 4,2 & 1, & & \\
& 5 & & 8 & 0,0 & Ada \\
& 2 & & 0, & 0 & $\begin{array}{l}\text { perbedaan } \\
\text { pignifikan }\end{array}$ \\
$\mathrm{a}$ & 5 & 1,5 & 5 & & \\
\hline
\end{tabular}

Berdasarkan tabel 2 didapatkan bahwa rerata intensitas nyeri pra inisiasi menyusui dini dalam waktu antara 3060 menit lebih tinggi yaitu 4,3 (SD 1,8) berbeda secara bermakna $(\mathrm{p}<0,05)$ daripada rerata pasca inisiasi menyusui dini yaitu 1,5 (SD 0,5) yang berarti intensitas nyeri ibu sesudah dilaku' inisiasi menyusui dini lebih rin 35 dibandingkan sebelum inisiasi menyusui dini.

Tabel 3Perbedaan antara intensitas nyeri ibu pasca pada kelompok inisiasimenyusui dini antara kurang dari 30 menit dan 30-60 menit

\begin{tabular}{|c|c|c|c|c|c|}
\hline $\begin{array}{l}\text { Pasc } \\
\text { a } \\
\text { IMD }\end{array}$ & $\mathrm{n}$ & $\begin{array}{c}\text { Rerat } \\
\text { a }\end{array}$ & $\begin{array}{l}\text { S } \\
\text { D }\end{array}$ & $\mathrm{p}$ & $\begin{array}{c}\text { Keteranga } \\
\mathrm{n}\end{array}$ \\
\hline $\begin{array}{l}<30 \\
\mathrm{mnt}\end{array}$ & 4 & 2,3 & $\begin{array}{c}0, \\
5\end{array}$ & $\begin{array}{c}0,1 \\
6\end{array}$ & Ada \\
\hline $\begin{array}{l}30- \\
60\end{array}$ & $\begin{array}{l}2 \\
5\end{array}$ & 3,2 & $\begin{array}{l}1, \\
3\end{array}$ & & perbedaan \\
\hline
\end{tabular}

mnt

Berdasarkan tabel 3 didapatkan bahwa rerata intensitas nyeri ibu pasca inisiasi menyusui dini kurang dari 30 menit lebih rendah yaitu 2,3 (SD 0,5) dibandingkan inisiasi menyusui dini 30-60 menit yaitu 3,2 (SD 1,3) tetapi $\mathrm{p}=0,16$ yang artinya tidak ada perbedaan yang signifikan intensitas nyeri pada kelompok kurang dari 30 menit dengan 30-60 menit sesudah dilakukan inisiasi menyusui dini.

\section{Diskusi}

Hasil analisis bivariat dengan menggunakan uji $\mathrm{T}$ sampel berpasangan untuk pra dan post inisiasi menyusui dini dan menggunakan uji $\mathrm{T}$ dua sampel bebas untuk mengetahui hubungan dua variabel yang tidak berpasangan hasilnya menunjukkan bahwa ada hubungan yang signifikan antara kecepatan inisiasi menyusui dini dengan penurunan intensitas nyeri ibu pada kala empat.

Nyeri adalah suatu sensasi yang tidak menyenangkan baik secara sensori maupun emosional yang berhubungan dengan adanya suatu kerusakan jaringan atau faktor lain, ehingga individu merasa tersiksa, .nenderita yang akhirnya akan mengganggu aktifitas sehari-hari, psikis dan lain-lain. Nyeri merupakan sensasi yang rumit, unik, universal dan bersifat individual, dikatakan bersifat individual karena respons individu terhadap sensasi nyeri beragam dan tidak bisa disamakan satu dengan yang lainnya (Asmadi, 2008)

$$
\text { Nyeri persalinan dapat }
$$
menimbulkan trauma karena rasa sakit yang dialami ibu sehingga perlu menerapkan cara yang tepat untuk mengatasi rasa nyeri persalinan 
tersebut. Nyeri adalah bagian integral dari persalinan dan melahirkan. Tidak seperti yang diyakini sebelumnya yaitu suatu hasil langsung dari pengaruh sosial, kultural dan emosional saja dalam masyarakat yang beradab, tetapi lebih pada kulminasi faktor fisiologis dan psikologis (Mander, 2004).

Salah satu cara yang bisa digunakan untuk mengalihkan perhatian pada rasa nyeri adalah dengan melakukan tehnik distraksi, salah satu caranya bisa dengan melakukan inisiasi menyusui dini. Menurut (Tamsuri, 2007) Distraksi adalah mengalihkan perhatian klien dari nyeri sehingga dapat meningkatkan ambang nyeri. Tehnik distraksi adalah pengalihan dari fokus perhatian terhadap nyeri ke stimulus yang lain. Tehnik distraksi dapat mengatasi nyeri berdasarkan teori bahwa aktivasi retikuler menghambat stimulus nyeri, jika seseorang menerima input sensori yang berlebihan dapat menyebabkan terhambatnya impuls nyeri ke otak (nyeri berkurang atau tidak dirasakan oleh klien). Stimulus yang menyenangkan dari luar juga danat merangsang sekresi endorfin, sehir 36 stimulus nyeri yang dirasakan olen klien menjadi berkurang.

Inisiasi menyusui dini merangsang pengeluaran kolostrum dan meningkatkan produksi kolostrum serta dapat meningkatkan produksi ASI. Selain kondisi bayi yang diuntungkan dari tindakan ini, dampak yang positif juga bisa ditemukan pada ibu yaitu ibu menjadi lebih tenang, mempercepat kelahiran plasenta dan pengalihan rasa nyeri dari berbagai prosedur pasca persalinan lainnya. Disamping merangsang pengeluaran hormon oksitosin juga hormon prolaktin yang sangat bermanfaat karena dapat meningkatkan produksi ASI, membantu ibu mengatasi stress terhadap berbagai rasa kurang nyaman dan memberi efek relaksasi pada ibu setelah bayi selesai menyusu (Aprilia, 2009). Pelaksanaan inisiasi menyusui dini akan merangsang hormon lain yang membuat ibu menjadi tenang, rileks, dan mencintai bayi, lebih kuat menahan sakit/nyeri karena hormon meningkatkan ambang nyeri, dan timbul rasa sukacita/bahagia (Ranggaahdiat, 2011).

Kelebihan tehnik distraksi inisiasi menyusui dini dibandingkan dengan tehnik yang lain adalah dengan inisiasi menyusui dini seluruh indra turut terlibat dalam proses ini dan secara psikologis hubungan kasih sayang antara ibu dan bayi menjadi lebih erat sehingga ibu akan teralihkan perhatiannya ke bayinya, oleh karena itu stimulasi penglihatan, pendengaran dan sentuhan mungkin akan lebih efektif dalam mengalihkan perhatian terhadap rasa nyeri dibanding stimulasi satu indera saja. Sehingga dalam penelitian ini ada perbedaan yang signifikan antara intensitas nyeri ibu sebelum dan sesudah dilakukan inisiasi menyusui dini, sedangkan untuk intensitas nyeri ibu baik yang lebih cepat maupun yang lambat dalam melakukan inisiasi menyusui dini tidak ada perbedaan yang signifikan.

Pengalaman nyeri pada seseorang dapat dipengaruhi oleh beberapa hal, diantaranya adalah: yang pertama arti nyeri,arti nyeri ini bagi seseorang memiliki banyak perbedaan dan hampir sebagaian arti nyeri merupakan arti yang negatif, seperti membahayakan, merusak dan lain-lain. Keadaan ini dipengaruhi oleh berbagai faktor, seperti usia, jenis kelamin, latar 
belakang sosial budaya, lingkungan dan pengalaman. Yang kedua persepsi nyeri yaitu merupakan penilaian yang sangat subjektif tempatnya pada korteks.Persepsi ini dipengaruhi oleh faktor yang dapat memicu stimulasi nociceptor. Yang ketiga adalah toleransi nyeri, hal ini erat hubungannya dengan intensitas nyeri yang dapat mempengaruhi kemampuan seseorang menahan nyeri.Faktor yang dapat mempengaruhi peningkatan toleransi nyeri antara lain alkohol, obat-obatan, hipnotis, gesekan atau garukan, pengalihan perhatian, kepercayaan yang kuat dan sebagainya.Sedangkan faktor yang menurunkan toleransi antara lain kelelahan, rasa marah, bosan, cemas, nyeri yang tidak kunjung hilang, sakit dan lain-lain.Yang keempat reaksi terhadap nyeri yang merupakan bentuk respons seseorang terhadap nyeri, seperti ketakutan, gelisah, cemas, menangis dan menjerit. Semua ini merupakan bentuk respons nyeri yang dapat dipengaruhi oleh beberapa faktor, seperti arti nyeri, tingkat persepsi nyeri, pengalaman masa lalu,nilai budaya, harapan social, kesehatan fisik dan mental, rasa takut, cemas, usia dan lain-lain (Aziz, 2006).

Ada beberapa hasil penelitian yang berkaitan dengan Inisiasi menyusui dini terkait dengan penurunan rasa nyeri setelah persalinan antara lain: Penelitian Matthiesen 2001, Kroeger \& Smith 2004 menyatakan bahwa inisiasi menyusui dini dapat mengurangi rasa sakit, Ibu lebih tenang, rileks, lebih mencintai bayinya dan perasaan sangat bahagia. Penelitian UNICEF India: Breast crawl initiation of breastfeeding by breast crawl. UNICEF India 2007, dengan melaksanakan inisiasi menyusui dini maka sentuhan, hisapan, jilatan pada puting susu ibu merangsang produksi hormon oksitosin. Penelitian Matthiesen et al 2001, menunjukkan bahwa oksitosin akan membuat ibu tenang dan rileks dan meningkatkan ambang nyeri (Purnamasari, 2011).

Berdasarkan hasil beberapa penelitian di atas, inisiasi menyusui dini dapat meningkatkan ambang nyeri ibu karena dengan adanya hisapan bayi pada puting susu ibu akan menimbulkan rangsangan produksi hormon oksitosin yang membuat ibu lebih tenang dan rileks. Ibu akan merasa senang, bahagia dan rileks sambil memperhatikan bayinya tetapi karena rasa nyeri ini sangat subyektif dan individual maka dengan demikian rasa nyeri yang dirasakan ibu tidak ada perbedaan antara yang lebih cepat dengan yang lebih lambat dalam melakukan inisiasi menyusui dini, tetapi ada perbedaan yang signifikan intensitas nyeri antara sebelum dan sesudah dilakukan inisiasi menyusui dini.

Hal ini juga bisa didukung dari usia responden yang sebagian besar berusia lebih dari 20-30 tahun yang termasuk dalam kategori usia dewasa, bila mengalami rasa sakit lebih bisa mengungkapkan dibandingkan pada anak-anak. Menurut (Syariah, 2012) usia merupakan variabel yang penting mempengaruhi nyeri.

\section{Simpulan}

Setelah dilakukan analisis data, dapat disimpulkan bahwaterdapat hubungan yang signifikan antara kecepatan inisiasi menyusui dini dengan penurunan intensitas nyeri ibu setelah melahirkan di Ruang Dahlia I RSU USD Gambiran Kediri, sehingga ada perbedaan yang signifikan intensitas 
nyeri ibu antara sebelum dan sesudah dilakukan inisiasi menyusui dini karenadengan melaksanakan inisiasi menyusui dini sentuhan, hisapan, jilatan pada puting susu ibu merangsang produksi hormon oksitosin danhormon oksitosin akan membuat

\section{DAFTAR PUSTAKA}

Aprilia. (2009). Analisis Sosialisasi Program Inisiasi Menyusui Dini Dan Asi Eksklusif Kepada Bidan Di Kabupaten Klaten. Tesis. Universitas Diponegoro. Semarang

Bobak.,Lowdermilk.,Jensen. (2004). Keperawatan Maternitas edisi 4. Jakarta: Penerbit Buku Kedokteran EGC.

Chandra, Budiman. (2007). Metodologi Penelitian Kesehatan. Jakarta: Penerbit Buku Kedokteran EGC

Cunningham., Gant., Leveno.,Gilstrap., Hauth., Wenstrom. (1995). Obstetri William. Jakarta: Penerbit Buku Kedokteran EGC.

Frisda.(2010). Faktor-faktor Pada bidan Yang Mempengaruhi Praktik Inisiasi Menyusui Dini.Tesis.Universitas Diponegoro Semarang.

Gusnita.(2008). Inisiasi Menyusui Dini Cegah Perdarahan Ibu Melahirkan.http://news.detik.com/rea d/2008/08/03/101215/981982/10/inis iasimenyusu-dini-cegah-pendarahanibu-melahirkan. diakses tanggal 22 Januari 2015.

Haryanti.(2011 ). Faktor-faktor Yang Mempengaruhi Pelaksanaan Inisiasi Menyusui Dini.Skripsi. Stikes Muhammadiyah Gombong-Jawa Tengah.

Hernawati.(2011). Analisis Kematian Ibu Di Indonesia 2010. Jakarta: Riskesdas dan Laporan Rutin KIA.

Idris.(2009).Peran Faktor Perilaku Dalam Penerapan Inisiasi Menyusui Dini di ibu tenang dan rileks dan meningkatkan ambang nyeri.

Kota Pare Pare.Tesis.Universitas Hasanuddin Makasar.

Lowdermilk.,Bobak.,Jensen. (1999). Maternity Nursing $5^{\text {th }}$ edition. Missouri: Mosby Year Book

Mander.(2004). Nyeri Peralinan. Jakarta: Penerbit Buku Kedokteran EGC

Manuaba (1998).Ilmu Kebidanan, Penyakit Kandungan \& Keluarga Berencana untuk Pendidikan Bidan. Jakarta: Penerbit Buku Kedokteran EGC

Potter, Patricia A \& Perry, Anne G. (1997).Fundamental of Nursing.Concepts, Process, and Practice. Missouri: Mosby Year Book

Rachmawati. (2008). Analisis Teori Nyeri: Keseimbangan Antara Analgesik Dan Efek Samping.Jurnal Keperawatan Indonesia. Volume 12, No.2, Juli 2008 ISSN 1410-4490.

Roesli, Utami (2008). Inisiasi Menyusui Dini. Jakarta: Penerbit Buku Kedokteran EGC

Setiadi (2007).Konsep dan Penulisan Riset Keperawatan. Yogyakarta: Penerbit Graha Ilmu

Sudiharto (1996).Asuhan Keperawatan pada Pasien Nyeri. Jakarta: Penerbit Buku Kedokteran EGC

Tamsuri, A.(2006). Konsep dan Penatalaksanaan Nyeri. Jakarta: Penerbit Buku Kedokteran EGC

Zuliani.(2011). Program Pelaksanaan IMD di Indonesia.

http://elvizulianisehatidotcom.wordpr ess.com/category/kesehatan-populer/ diakses tanggal 16 Maret 2015 